\title{
Kebijakan Reformasi Maqâshid al-Syarîah dan Kontribusinya dalam Formulasi Alternatif Keringanan Pidana Penjara
}

\author{
Iqbal Kamalludin \& Barda Nawawie Arief
}

\begin{abstract}
Maqâshid al-Sharîah Reform Policy and Its Contributions to Alternative Formulation of Imprisonment Reduction. Criminal law is often built on the paradigm of giving suffering to perpetrators of crime. This paradigm is no longer in accordance with the concept of modern punishment which focuses on efforts to foster criminals so that they would no longer repeat their actions. The changes in the paradigm of punishment, to some extent, have been accommodated by Article 73 of the Criminal Code Bill which contains alternative provisions/criminal sanctions.in jail. With this provision, a prisoner with one year or under punishment is able to repay his sentence as long as there are certain emergency conditions leading to a precarious situation/worry to him if he has to undergo consecutive penalties. This study tries to examine the new provision, using a normative juridical approach from the perspective of Islamic law. This study concludes that the paradigmatic change in punishment as shown in article 73 of the Criminal Code Bill has conformity with the perspective of maqâshid al-syarîah which put forward the 5 (five) main objectives in the law, namely maintaining and nurturing religion (al-dîn), soul (al-nafs), descent (al-nasl), wealth (al-mâl), and mind (al-aql).
\end{abstract}

Keywords: legal renewal, imprisonment reduction, maqâshid al-sharî̀ah

\begin{abstract}
Abstrak: Kebijakan Reformasi Maqâshid al-Syarîah dan Kontribusinya dalam Formulasi Alternatif Keringanan Pidana Penjara. Hukum pidana seringkali dibangun atas paradigma pemberian penderitaan pada pelaku kejahatan. Paradigma demikian ini sudah tidak lagi sesuai dengan konsep hukuman modern yang menitik beratkan pada upaya pembinaan pelaku kejahatan agar insyaf dan tidak lagi mengulangi perbuatannya. Perubahan paradigma hukuman yang demikian sampai taraf tertentu telah diakomodir pasal 73 RUU KUHP yang memuat ketentuan alternatif/keringanan pelaksanaan pidana penjara. Dengan adanya ketentuan tersebut seorang narapidana satu tahun ke bawah dimungkinkan mencicil hukumannya sepanjang ada kondisi darurat tertentu yang dapat menimbulkan situasi genting/menghawatirkan pada dirinya jika ia menjalani pidananya secara berturut-turut. Studi ini mencoba menelaah permasalahan tersebut dengan menggunakan pendekatan yuridis normatif dari perspektif hukum Islam. Studi ini menyimpulkan bahwa perubahan paradigma hukuman sebagaimana ditampakkan dalam pasal 73 RUU KUHP memiliki kesesuaian dengan perspektif maqâshid al-syarî̀ah yang mengedepankan 5 (lima) tujuan utama dalam hukum, yaitu menjaga dan memelihara agama (al-dîn), jiwa (al-nafs), keturunan (al-nasl), harta (al-mâl) dan akal (al-aql).
\end{abstract}

Kata Kunci: pembaharuan hukum, pidana penjara, maqâshid al-syarî̉ah

Magister Ilmu Hukum, Fakultas Hukum, Universitas Diponegoro

Jl. Imam Bardjo No.1-3 Pleburan, Kota Semarang, Jawa Tengah 50241

E-mail: ena_feriana@yahoo.co.id \& kamalludin.iqbal@gmail.com 


\section{Pendahuluan}

Saat ini kerusuhan di dalam Lembaga Pemasyarakatan di berbagai daerah kerap terjadi. ${ }^{1}$ Pada tahun 2016, banyaknya orang yang dipenjara dan ditahan mencapai lebih dari 190.000. Angka ini jauh melebihi kapasitas lembaga pemasyarakatan (LP) dan rumah tahanan (Rutan) yang dimiliki saati ini. Pemerintah Indonesia kurang menyadari bahwa dampak dari penambahan jenis tindak pidana adalah penambahan sumber daya baik uang maupun orang untuk menindaknya. ${ }^{2}$

Selain masalah kerusuhan yang kemudian kerap terjadi, kemampuan finansial anggaran pendapatan dan belanja negara pun tidak akan mampu menangung biaya pembangunan Rutan atau Lapas baru jika jumlah tahanan terus menerus bertambah, di samping biaya operasionalnya yang juga menjadi beban negara. ${ }^{3}$ Tren penambahan dan membludaknya jumlah tahanan tanpa diikutinya perubahan kondisi lapas dapat menjadi "bom waktu" dalam waktu ke depan. Sementara itu, tidak hanya kondisi lapas yang seharusnya dipersalahkan, karena regulasi tentang pemidanaan saat ini yang seharusnya mendapat perhatian lebih. Alternatif pemidanaan, paradigma baru di dalam melihat penanganan permasalahan narapidana harus betul-betul direformasi.

Seperti diketahui, pidana penjara adalah suatu pidana berupa perampasan kemerdekaan atau kebebasan bergerak dari seorang terpidana

${ }^{1}$ Penelitian terkait kerusuhan yang kerap terjadi di lapas bisa dilihat pada beberapa artikel di antaranya Ismail Rumadan, "Problem Lembaga Pemasyarakatan di Indonesia dan Reorientasi Tujuan Pemidanaan." Jurnal Hukum dan Peradilan 2, no. 2 (2013): h. 263-276. Theresia Avila Ledie Naintyla, "Kerusuhan Narapidana dalam Lembaga Pemasyarakatan (Studi di Lembaga Pemasyarakatan Kelas IIA Wirogunan Yogyakarta).” PhD diss., UAJY, 2010. Luh Putu Shanti Kusumaningsih, "Studi Kasus: Derajat Social Anxietypada Narapidana di Lapas Brebes." Intuisi: Jurnal Psikologi Ilmiah 8, no. 1 (2016): h. 14-19. I. Putu Satrya Wibawa Sukarsa Putra, "Dampak Kelebihan Kapasitas Lembaga Pemasyarakatan Sebagai Faktor Kriminogenik Terhadap Pengulangan Tindak Pidana oleh Warga Binaan (Studi di Lapas Kelas II A Denpasar)." Kumpulan Jurnal Mahasiswa Fakultas Hukum (2015). Ulang Mangun Sosiawan, "Upaya Penanggulangan Kerusuhan di Lembaga Pemasyarakatan." Jurnal Penelitian Hukum De Jure 17, no. 3 (2017): h. 365-379. Asnedi, "Pengelolaan Lembaga Pemasyarakatan dengan Segala Permasalahannya." Jurnal Pemerintahan dan Politik 1, no. 1 (2016). Astrid Azizy, "Faktor Penyebab Terjadinya Kerusuhan dan Anarki Serta Upaya Penanggulangannya (Studi di Rumah Tahanan Negara Klas 1 Surabaya).” PhD diss., Universitas Brawijaya, 2013.

2 Choky Ramadhan, Pengantar Analisis Ekonomi dalam Kebijakan Pidana di Indonesia (Jakarta: Institute for Criminal Justice Reform (ICJR), 2016), h. 1.

${ }^{3}$ Choky Ramadhan, Pengantar Analisis Ekonomi dalam Kebijakan Pidana di Indonesia, h. 1 
dengan menempatkannya di lembaga pemasyarakatan. ${ }^{4}$ Pidana penjara merupakan, jenis pidana yang paling banyak diancamkan kepada pelaku tindak pidana dalam Buku II KUHP. Pidana penjara juga diancamkan terhadap tindak pidana yang diatur dalam undang-undang di luar KUHP, baik dirumuskan secara tunggal maupun secara kumulatif-alternatif dengan sanksi pidana lainnya.

Permasalahan yang terjadi dalam hukum juga berkembang sesuai dengan pola perkembangan masyarakat Indonesia. Aturan yang terdahulu sudah tidak sesuai lagi dengan perkembangan masyarakat dan tidak sesuai lagi dengan perkembangan zaman. ${ }^{5}$ Membatasi dan melindungi kepentingan-kepentingan manusia dalam pergaulan antar manusia adalah tugas hukum. ${ }^{6}$ Oleh karenanya perlu pembaruan dalam bidang hukum apabila terdapat aturan-aturan yang sudah tidak sesuai lagi terutama hukum pidana.

Menurut Sudarto seperti dikemukakan oleh Barda Nawawie Arief, terdapat 3 (tiga) alasan perlunya memperbarui KUHP, yakni alasan sosiologis, politis, dan praktis (kebutuhan dalam praktik): ${ }^{7}$

1. Dari segi politik, wajar bagi bangsa Indonesia yang sudah merdeka untuk mempunyai KUHP sendiri karena hal itu adalah merupakan simbol (lambang) dari kebanggaan sebagai bangsa yang telah merdeka.

${ }^{4}$ Dwidja Priyatno, Sistem Pelaksanaan Pidana Penjara di Indonesia (Bandung: Refika Aditama, 2009), h. 71.

${ }^{5}$ Banyak hal dalam hukum yang terus berkembang di Indonesia, baik hukum Islam, hukum positif dan hukum adat. Selengkapnya terkait hal ini bisa dilihat pada M Sularno, "Syari'at Islam dan Upaya Pembentukan Hukum Positif di Indonesia." Al-Mawarid 16 (2006). Lastuti Abubakar, "Revitalisasi Hukum Adat Sebagai Sumber Hukum dalam Membangun Sistem Hukum Indonesia." Jurnal Dinamika Hukum 13, no. 2 (2013): h. 319-331. Fikria Najitama, "Sejarah Pergumulan Hukum Islam dan Budaya serta Implikasinya bagi Pembangunan Hukum Islam Khas Indonesia." Al-Mawarid 17 (2007). Amir Mu’allim, "Adat Kebiasaan dan Kedudukannya dalam Perkembangan Hukum Islam di Indonesia." Al-Mawarid 4 (2016): h. 14-23. Agung Setiyawan, "Budaya Lokal dalam Perspektif Agama: Legitimasi Hukum Adat ('Urf) dalam Islam." Esensid: Jurnal Ilmu-Ilmu Ushuluddin 13, no. 2 (2012): h. 203-222. Sirojul Munir, "Pengaruh Hukum Islam Terhadap Politik Hukum Indonesia." Istinbath: Jurnal Hukum Islam IAIN Mataram 13, no. 2 (2014): h. 127-180. Abdul Hadi, dan Shofyan Hasan, "Pengaruh Hukum Islam dalam Pengembangan Hukum di Indonesia." Nurani: Jurnal Kajian Syariah dan Masyarakat 15, no. 2 (2015): h. 89-100.

${ }^{6}$ Barda Nawawie Arief, Perbandingan Hukum Pidana, Edisi Revisi, (Jakarta: Raja Grafindo, 2010), h.15.

Sudarto, Hukum Pidana dan Perkembangan Masyarakat (Bandung: Sinar Baru, 1983), h. 66. 
2. Karena dalam teks resmi KUHP adalah berbahasa Belanda maka sehubungan dengan hal itu, tidaklah cocok dengan Bahasa Indonesia yang sudah mendarah daging dari Bangsa Indonesia ini.

3. Secara sosiologis, KUHP tidak mencerminkan nilai-nilai yang hidup dalam masyarakat Indonesia. Ini tentunya bertentangan dengan masalah kebudayaan, di sisi lain KUHP Belanda berdasarkan sistem kapitalisme, dan liberal. Sementara bangsa Indonesia berdasarkan kebersamaan, kekeluargaan. Maka dari itulah sudah tidak cocok bahwa KUHP untuk diterapkan di Indonesia.

Menurut Barda Nawawi Arief, ${ }^{8}$ jika dilihat dari sudut dogmatif, permasalahan pokok dari hukum pidana adalah:

1. Perbuatan apa yang sepatutnya dipidana, atau biasa disingkat dengan "tindak pidana"

2. Syarat apa yang seharusnya dipenuhi untuk menyalahkan atau mempertanggungjawabkan seseorang yang melakukan perbuatan itu, atau biasa disebut dengan masalah "kesalahan", dan

3. Sanksi (pidana) apa yang sepatutnya dikenakan kepada orang yang disangka melakukan perbuatan pidana, atau biasa disebut dengan masalah "pidana".

Perwujudan kebijakan sanksi pidana yang dipandang dari sudut operasionalisasi atau fungsionalisasi (bekerjanya hukum pidana), maka dapat dibedakan dalam 3 (tiga) tahap, yaitu: ${ }^{9}$

1. Tahap Formulasi, yaitu tahap penetapan hukum pidana mengenai macam perbuatan yang dapat dipidana dan jenis sanksi yang dapat dikenakan. Kekuasaan yang berwenang dalam melaksanakan tahap ini adalah kekuasaan legislatif/formulatif;

2. Tahap Aplikasi, yaitu tahap dalam menerapkan hukum pidana, atau penjatuhan pidana kepada seseorang atau korporasi oleh hakim atas perbuatan yang dilakukan oleh orang tersebut. Yang berwenang

${ }^{8}$ Barda Nawawi Arief, Beberapa Aspek Kebijakan Penegakan dan Pengembangan Hukum Pidana (Bandung: Citra Aditya Bakti, 1998), h. 111.

${ }^{9}$ Barda Nawawi Arief, Beberapa Aspek Kebijakan Penegakan dan Pengembangan Hukum Pidana, h. 99. 
dalam tahap ini adalah kekuasaan aplikatif/yudikatif; dan

3. Tahap Eksekusi, yaitu tahap pelaksanaan pidana oleh aparat eksekusi pidana atas orang atau korporasi yang telah dijatuhi pidana tersebut. Kewenangan dalam hal ini ada pada kekuasaan eksekutif/administratif.

Pembaharuan hukum pidana harus dilakukan dengan pendekatan kebijakan, karena memang pada hakikatnya ia hanya merupakan bagian dari suatu langkah kebijakan atau "policy" (yaitu bagian dari politik hukum/ penegakan hukum, politik hukum pidana, politik kriminal dan politik sosial). Di dalam setiap kebijakan (policy) terkandung pula pertimbangan nilai. Oleh karena itu, pembaruan hukum pidana harus pula berorientasi pada pendekatan nilai. ${ }^{10}$

Menurut Muladi seperti dikutip Nyoman Serikat dalam buku Pembaharuan Hukum Pidana, dalam rangka pembaharuan hukum pidana melalui pembuatan RUU KUHP ini tidak lepas dari orientasi ideologi nasional, kondisi manusia, alam dan tradisi bangsa maupun dari perkembangan internasional yang diakui oleh masyarakat beradab. Inilah yang dinamakan Asas Pertimbangan Kepentingan Yang berwawasan Pancasila sebagai pengejawantahan "Asas Hukum Pidana Nasional". ${ }^{11}$

Dalam hal pemidanaan terkait dengan stelsel pidana penjara, ada kecenderungan, pidana penjara mengalami degradasi, karena mendapat banyak tantangan dan tekanan dari berbagai gerakan yang muncul di Eropa dan Amerika, sorotan keras terhadap pidana penjara tidak hanya diberikan oleh para pakar secara individual, melainkan juga oleh lembaga-lembaga internasional. Laporan kongres PBB kelima tahun 1975 mengenai Pencegahan Kejahatan dan Pembinaan Pelaku Kejahatan, ada kecenderungan untuk mengabaikan kemampuan lembaga-lembaga kejahatan. Pada perkembangan selanjutnya muncul gerakan abolisionis di Amerika yang menekankan reaksinya pada penghapusan sistem penjara dan gerakan abolisionis Eropa yang menekankan penolakannya terhadap sistem peradilan pidana secara keseluruhan, dengan sentralnya sistem

${ }^{10}$ Barda Nawawi Arief, Bunga Rampai Kebijakan Hukum Pidana (Semarang: Kencana Prenada Media Group, 2014), h. 29.

${ }^{11}$ Nyoman Serikat Putra Jaya, Pembaharuan Hukum Pidana (Semarang: Pustaka Rizki Putra, 2017), h.17-18. 
kepenjaraan dengan memunculkan jenis pidana alternatif seperti denda dan kerja sosial. Walaupun demikian, pidana penjara dianggap masih diperlukan untuk menghadapi berbagai kejahatan yang semakin banyak ragam dan modusnya. ${ }^{12}$ Meskipun demikian, menurut Barda Nawawi Arief banyak kritikan ditujukan terhadap pidana penjara. Secara garis besar, kritik tersebut terdiri dari kritik yang moderat dan kritik yang ekstrem. Kritik moderat pada intinya masih mempertahankan pidana penjara namun penggunaannya dibatasi, sedangkan kritik yang ekstrim menghendaki penghapusan pidana penjara. Gerakan penghapusan pidana penjara (prison abolition) ${ }^{13}$ ini terlihat dengan adanya International Confrence On Prison abolition (ICOPA) yang diselenggarakan pertama kali pada bulan Mei 1983 di Toronto Kanada, yang ke-2 pada tanggal 24-27 Juni 1985 di Amsterdam dan yang ke-3 pada tahun 1987 di Montreal, Kanada. Pada konfrensi ke-3 ini istilah "prison aboltion" telah diubah menjadi "penal abolition". ${ }^{14}$

Salah satu tokoh gerakan "prison abolition" ini adalah Herman Bianchi ${ }^{15}$ seperti dikemukakan oleh Barda Nawawie Arief menyatakan:

${ }^{12}$ Muhammad Fajar Septiano, Jurnal Pidana Kerja Sosial Sebagai Alternatif Pidana Penjara Jangka Pendek. (Malang: UB, 2014), h. 11

${ }^{13}$ Terkait artikel tentang prison abolition dapat dilihat pada beberapa karya akademis di antaranya Angela Y Davis, "Racialized Punishment and Prison Abolition." A Companion to African-American Philosophy (2006): h. 360-369. Angela Y. Davis, and Dylan Rodriguez. "The Challenge of Prison Abolition: A Conversation." Social Justice 27, no. 3 (81 (2000): h. 212-218. Beth E. Richie, "Reimagining the Movement to End Gender Violence: Anti-Racism, Prison Abolition, Women of Color Feminisms, and Other Radical Visions of Justice." U. Miami Race \& Soc. Just. L. Rev. 5 (2015): h. 257. Kim Gilmore, "Slavery and Prison-Understanding the Connections." Social Justice 27, no. 3 (81 (2000): h. 195-205. Damon Mayrl, "Fields, Logics, and Social Movements: Prison Abolition and the Social Justice Field." Sociological Inquiry 83, no. 2 (2013): h. 286-309. J. D. Bessler, Revisiting Beccaria's Vision: The Enlightenment, America's Death Penalty, and the Abolition Movement. Nw. JL \& Soc. Pol'y, 4, (2009), h. 195.

${ }^{14}$ Barda Nawawi Arief, Kapita Selekta Hukum Pidana (Bandung: Citra Aditya Bakti, 2010), h. 33.

15 Pemikiran Herman Bianchi bisa dilihat dalam tulisannya Herman Bianchi, and René van Swaaningen, eds. Abolitionism: Towards a Non-repressive Approach to Crime: Proceedings of the Second International Conference on Prison Abolition, Amsterdam 1985: with Contributions from Elizabeth Barker...[et Al.]. Free University Press, 1986. Herman Bianchi, "Abolition: Assensus and Sanctuary." Abolitionism: Towards a Non-Repressive Approach to Crime (1986): h. 113-126. Herman Bianchi, "Pitfalls and Strategies of Abolition." Abolitionism: Towards a Non-Repressive Approach to Crime, Free University Press, Amsterdam (1986). Herman, Bianchi, and H. Bianchi. Justice as Sanctuary: Toward A New System of Crime Control. Vol. 15. Bloomington: Indiana University Press, 1994. 
"The Institution of prison and imprisonment are to be for ever abolished, entirely and totally. No trace should be lift of this darkside in human history." ("Lembaga penjara dan pidana penjara harus dihapuskan untuk selama-lamanya dan secara menyeluruh. Tidak sedikitpun (bekas) yang patut diambil dari sisi yang gelap di dalam sejarah kemanusiaan ini")

Pendapat untuk menghapuskan pidana penjara di Indonesia telah dikemukakan oleh Hazairin. (seperti dalam Barda Nawawie Arief ) sejak tahun 1972 dalam tulisannya yang berjudul Negara tanpa Penjara. Hingga saat ini, upaya untuk mencapai tujuan perlindungan masyarakat dan kesejahteraan masyarakat masih terus diupayakan dan dicarikan rumusan tepatnya terlebih melihat kondisi bangsa dan budayanya.

Adanya pemidanaan pada hakikatnya untuk mencapai tujuan dari pemidanaan itu sendiri. Seperti yang dikemukakan Barda Nawawi Arief, dirumuskannya tujuan pemidanaan sudah dimulai sejak konsep pertama tahun 1964 sampai dengan konsep 2008. Pada awalnya Konsep 1964 dan 1968, di samping ada perumusan mengenai tujuan pemidanaan, ada juga perumusan tentang "tujuan hukum pidana". Pasal 54 RKUHP menegaskan bahwa tujuan pemidanaan dirumuskan sebagai berikut: ${ }^{16}$

(1) Pemidanaan bertujuan:

a. Mencegah dilakukannya tindak pidana dengan menegakkan norma hukum demi pengayoman masyarakat;

b. Memasyarakatkan terpidana dengan mengadakan pembinaan sehingga menjadi orang yang baik dan berguna;

c. Menyelesaikan konflik yang ditimbulkan oleh tindak pidana, memulihkan keseimbangan dan mendatangkan rasa damai dalam masyarakat;

d. Membebaskan rasa bersalah pada terpidana;

(2) Pemidanaan tidak dimaksudkan untuk memenderitakan dan merendahkan martabat manusia

Konsep tersebut di atas yang kemudian melatarbelakangi diadakannya pembaharuan pada penjatuhan pemidanaan, salah satunya

${ }^{16}$ Barda Nawawi Arief, Tujuan dan Pedoman Pemidanaan ( Semarang: Pustaka Magister, 2017), h. 16. 
dengan dicetuskannya alternatif dalam pelaksanaan penjara. Mengingat pelaksanaan norma yang terkandung pada KUHP warisan Belanda yang masih dipraktikan hingga saat ini ternyata sama sekali tidak membuat para pelaku tindak pidana jera, justru kemudian semakin banyak penderitaanpenderitaan yang timbul, meresahkan dan berbahaya. Hal ini juga dapat dilihat dari semakin over capacity lapas-lapas yang ada di Indonesia belum menunjukkan arah untuk adanya penurunan jumlah penghuni. Seperti diketahui, bagian yang terpenting dalam sistem pemidanaan dalam arti yang sempit adalah menetapkan suatu sanksi. Keberadaannya dalam penentuan sanksi yaitu akan memberikan arah dan pertimbangan mengenai apa yang seharusnya dijadikan sanksi dalam suatu tindak pidana untuk menegakan berlakunya norma hukum.

Pengaturan jenis-jenis sanksi yang diterapkan di dalam KUHP $(W v S)$, khususnya dalam Pasal 10 KUHP yakni:

a) Pidana pokok terdiri dari pidana mati, pidana penjara, pidana kurungan, pidana denda, dan pidana tutupan. ${ }^{17}$

b) Pidana tambahan terdiri dari pencabutan hak-hak tertentu, perampasan barang-barang tertentu, dan pengumuman putusan hakim.

Sementara itu, dalam rancangan KUHP (2015), sanksi penjara ternyata masih masuk di dalam stelsel pidana. Hal ini dicantumkan di dalam Pasal 66

(1) Pidana pokok terdiri atas pidana penjara, pidana tutupan, pidana pengawasan, pidana denda dan pidana kerja sosial.

(2) Urutan pidana sebagaimana dimaksud pada ayat (1) menentukan berat ringannya pidana, kecuali pidana bagi anak.

Hal yang menarik, karena terdapat perbedaan dari KUHP (WvS), karena di dalam RKUHP, pidana penjara ini dalam pelaksanaannya memuat asas fleksibilitas, terlihat dari Pasal 73 berikut:

${ }^{17}$ Berdasarkan Undang-undang Nomor 20 Tahun 1946 tentang Pidana Tutupan 
Pasal 73

(1) Dalam hal hakim menjatuhkan pidana penjara 1 (satu) tahun atau kurang dari 1 (satu) tahun maka hakim dapat menetapkan pelaksanaan pidana dengan jalan mengangsur.

(2) Pelaksanaan pidana penjara angsuran sebagaimana dimaksud pada ayat (1) hanya dapat diberikan apabila hakim mempertimbangkan adanya kondisi yang sangat gawat atau menimbulkan akibat lain yang sangat mengkhawatirkan apabila terdakwa menjalani pidananya secara berturut-turut.

(3) Ketentuan mengenai pelaksanaan pidana angsuran sebagaimana dimaksud pada ayat (1) dapat dilaksanakan paling lama 2 (dua) hari dalam 1 (satu) minggu atau 10 (sepuluh) hari dalam sebulan dengan ketentuan jumlah atau lama angsuran tidak melebihi 3 (tiga) tahun.

Pasal 73 di atas mengakomodir cita-cita alternatif pelaksanaan pidana penjara, hakim diberikan wewenang untuk diperbolehkan menjatuhkan putusan pelaksanaan pidana dengan cara diangsur dengan beberapa ketentuan, di antaranya:

a. Penjatuhan pidana penjara 1 tahun atau kurang dari 1 tahun.

b. Hanya dapat diberikan apabila ada kondisi yang sangat gawat atau menimbulkan akibat lain yang sangat mengkhawatirkan apabila terdakwa menjalani pidananya secara berturut-turut.

c. dapat dilaksanakan paling lama 2 (dua) hari dalam 1 (satu) minggu atau 10 (sepuluh) hari dalam sebulan dengan ketentuan jumlah atau lama angsuran tidak melebihi 3 (tiga) tahun.

Dalam hal ini, seperti dikatakan oleh Barda Nawawi Arief, pembaharuan hukum pidana merupakan 'masalah besar' yang sedang dihadapi oleh bangsa Indonesia. Masalah yang besar dihadapi itu ialah masalah memperbaharui dan mengganti produk-produk-produk kolonial di bidang hukum pidana, khususnya pembaharuan KUHP (WvS) warisan Hindia Belanda yang merupakan induk dari keseluruhan sistem hukum pidana Indonesia saat ini. ${ }^{18}$

18 Barda Nawawi Arief, Beberapa Aspek Pengembangan Ilmu Hukum Pidana: Pidato Pengukuhan, diucapkan pada Peresmian Penerimaan Jabatan Guru Besar dalam Ilmu Hukum Pada Fakultas Hukum Universitas Diponegoro, Semarang 25 Juni 1994, h. 13. 
Semangat pembaharuan hukum pidana nasional juga pernah disampaikan oleh Sudarto, bahwa hukum pidana dari suat bangsa merupakan indikasi yang sangat penting untuk mengetahui tingkat peradaban suatu bangsa, karena di dalamnya tersirat bagaimana pandangan bangsa tersebut tentang etik (tata-susila), kemasyarakatan dan moral keagamaan. Selanjutnya dunia internasional memandang bahwa pembaharuan hukum pidana merupakan hal yang harus dilakukan. Hal ini terungkap dalam beberapa kongres PBB tentang "The Prevention of Crime and The Treatmentof Offenders" yang diselenggarakan setiap lima tahun sekali, dalam kongres tersebut sering disinyalir bahwa sistem hukum pidana yang selama ini ada di beberapa Negara (terutama yang berasal dari hukum asing semasa zaman kolonial) pada umumnya bersifat "obsolete and unjust" (telah usang dan tidak adil serta "outmoded and unreal" ketinggalan zaman dan sudah tidak sesuai lagi dengan kenyataan). Alasannya, karena tidak berakar pada nilai-nilai budaya dan bahkan ada diskrepansi dengan aspirasi masyarakat serta tidak responsif dengan kebutuhan sosial masa kini. Hal inilah yang juga menjadi penyebab terjadinya kejahatan atau faktor kriminogen. ${ }^{19}$ Mengingat himbauan dunia internasional tersebut, maka menjadi sangat urgen kemudian untuk segera dilakukannya pembaharuan hukum pidana (sistem pemidanaan) dalam rangka penanggulangan kejahatan.

Semangat pembaharuan hukum pidana nasional secara berbeda juga pernah disampaikan oleh Sudarto, ${ }^{20}$ bahwa semangat pembaharuan hukum pidana nasional harus tetap berkisar pada manusia, sehingga ia tidak boleh sekali-kali meninggalkan nilai-nilai kemanusiaan, yaitu nilai kasih sayang terhadap sesama. Di samping itu, Moeljatno juga mengatakan bahwa dalam Negara Indonesia yang berdasarkan Pancasila ini, di mana terdapat sila ketuhanan, maka tiap ilmu pengetahuan (termasuk ilmu

${ }^{19}$ Hal ini tercantum di dalam laporan kongres PBB VI tahun 1980 di Caracas, Venezuela, yang menyatakan bahwa "acapkali, ketiadaan konsistensi antara undang-undang dengan kenyataan merupakan faktor kriminogen, semakin jauh UU bergeser dari perasaan dan nilai-nilai hukum yang hidup di masyarkaat, semakin besar ketidakpercayaan dan keefektifan sistem hukum itu. Lihat Barda Nawawi Arief, Beberapa Aspek Kebijakan Penegakan dan Pengembangan Hukum Pidana (Bandung: Citra Aditya Bakti, 2005), h. 9.

${ }^{20}$ Sudarto, Hukum Pidana dan Perkembangan Masyarakat (Bandung: Sinar Baru, 1983), h. 102 . 
hukum) yang tidak dibarengi dengan ilmu ketuhanan atau nilai religious adalah tidak lengkap. ${ }^{21}$

Merupakan salah satu implementasi atau bentuk kajian ilmu hukum yang bersumber dari nilai-nilai religious atau ketuhanan, khususnya dari sudut kajian hukum Islam adalah "Maqâshid al-Syarîab". Maqâshid al-Syarîah bisa didefinisikan sebagai maksud atau tujuan-tujuan dari disyariatkannya hukum oleh syâri' ${ }^{22}$ merupakan suatu ilmu yang lahir dari kajian ushîl fiqh dalam melakukan istinbâth (penggalian) hukum. Sejarah berkembangnya maqâshid al-syarîah sendiri sebenarnya sudah ada sejak nash Alquran diwahyukan dan hadis disabdakan oleh Nabi Muhammad Saw karena maqâshid al-syarîah yang pada hakikatnya tidak pernah jauh dari sandaran nash, melainkan ia selalu menyertainya.

Sebagai bagian dari ajaran agama, teori maqâshid al-syarîah ingin mengatakan bahwa setiap ketentuan hukum, khususnya hukum pidana harus didekati dengan prinsip-prinsip Islam, di antaranya adalah bahwa agama Islam merupakan agama yang mendatangkan rahmat bagi seluruh alam semesta. Hal ini senada dengan Surat al-Anbiya' ayat 107 seperti berikut ini:

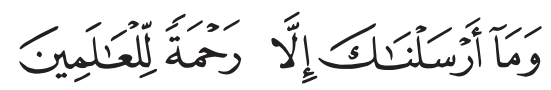

"Dan tidaklah kami mengutus kamu (Muhammad), melainkan untuk menjadi rahmat bagi semesta alam."

Sama halnya dengan hukum Islam, melalui melalui maqâshid alsyarîah yang ditujukan untuk mencapai, menjaga dan memelihara tiga skala prioritas yaitu dharûriyat, hajiyyat dan tahsiniyat. Maka menjadi suatu ironi tersendiri jika nilai-nilai yang tertuang dalam Alquran dan Hadis sebagai sumber otentik hukum Islam yang kemudian melahirkan maqâshid al-syarîah tidak diimplementasikan secara nyata dalam kepentingan kehidupan hukum bangsa Indonesia. Mengingat mayoritas masyarakat Indonesia ialah masyarakat muslim yang menginginkan hukum yang baik,

${ }^{21}$ Barda Nawawi Arief, Pembangunan Sistem Hukum Nasional Indonesia (Semarang: Penerbit Pustaka Magister, 2012), h. 32.

${ }^{22}$ Makhrus Munajat, Studi Islam di PerguruanTinggi (Yogyakarta: Pesantren Nawesea Press, 2008), h. 50. 
membawa maslahat dan keadilan dalam hidup berbangsa dan bernegara. Di samping itu, urgensi pengetahuan tentang maqâshid al-syarîah itu didasarkan pada beberapa pertimbangan.

Pertama, hukum Islam adalah hukum yang bersumber pada wahyu Allah Swt dan diperuntukkan bagi seluruh alam dan semua umat manusia. Oleh karena itu, ia akan selalu berhadapan dengan perubahan sosial. Dalam posisi yang demikian, timbul suatu pertanyaan "apakah hukum Islam dengan sumber hukum utamanya (Alquran dan Hadis) yang diwahyukan beberapa abad silam mampu beradaptasi dengan perubahan sosial saat ini, terutama dalam hal pidana penjara? Pertanyaan tersebut dapat terjawab setelah melakukan kajian mendalam terhadap berbagai elemen hukum Islam, dan salah satu elemen hukum Islam yang terpenting adalah teori maqâshid al-syarîah.

Kedua, dilihat dari aspek historis, sesungguhnya perhatian terhadap teori maqûshid al-syarìah telah dilakukan oleh Rasulullah Saw, para sahabat, dan generasi mujtahid sesudahnya. Ketiga, pengetahuan tentang maqâshid al-syarîah merupakan kunci keberhasilan mujtahid dalam ijtihadnya atau kunci bagi para ahli/pakar hukum dalam membuat hukum yang lebih baik.

\section{Implementasi Alternatif Keringanan Pidana Penjara di Berbagai Negara}

Alternatif pidana penjara sering dikenal dengan istilah asing "alternative to imprisonment", namun patut dikemukakan bahwa "alternatif pidana penjara tidak semata-mata diartikan sebagai alternatif dari "penjara" (imprisonment) sebagai jenis sanksi pidana, tetapi alternatif dari semua bentuk perampasan kemerdekaan yang menempatkan seseorang di dalam suatu lembaga/institusi atau tempat penahanan/pengurungan/terisolasi lainnya. Oleh karena itu istilah "alternative to imprisonment" sering juga dipadankan dengan istilah "alternative to incarceration", "alternative to custody" atau "noncustodial measures". Jadi dapat dikatakan alternatif pidana penjara adalah alternatif bentuk-bentuk sanksi atau tindakan noninstitusional. ${ }^{23}$

\footnotetext{
${ }^{23}$ Barda Nawawi Arief, Kapita Selekta Hukum Pidana, h. 267.
} 
Beberapa implementasi alternatif pidana penjara telah diterapkan di beberapa negara, dengan berbagai model seperti:

1. Semi-libertelsemi-detention (hanya malam hari masuk penjara) untuk pidana penjara pendek (tiga/enam bulan); night-time prison sentence. Pada mulanya semi liberte ini merupakan salah satu jenis dari pidana penjara malam hari (right time prison sentence), di mana para napi/ tahanan (the detainees) kembali ke penjara pada setiap sore setelah mengakhiri pekerjaannya. Menurut ketentuan ini, para napi hanya berada di penjara ketika mereka tidak terlibat dalam pekerjaan di luar penjara. Oleh karena itu, semi liberte lebih mempunyai ciri sebagai penahanan akhir minggu (week end detention). Bedanya, hari-hari di luar penjara pada semi liberte juga dihitung sebagai hari-hari penahanan. Ketentuan ini terdapat di dalam regulasi negara Perancis. UU No. 70-643 tanggal 17 Juli 1970 memasukkan ke dalam The Code of Criminal Procedure (CCP)/KUHAP, kemugkinan pidana penjara yang dijalani/dilaksanakan dalam bentuk semi liberte. Seorang hakim, ketika menjatuhkan pidana penjara 6 bulan atau kurang, dapat memberi kesempatan kepada terpidana untuk menjalani pidananya di luar lembaga penjara untuk mengikuti kursus pelatihan atau studi lainnya, melakukan pekerjaan atau menjalani perawatan medis. ${ }^{24}$

Pada mulanya semi liberte ini merupakan salah satu jenis dari pidana penjara malam hari (right time prison sentence), di mana para napi/ tahanan (the detainees) kembali ke penjara pada setiap sore setelah mengakhiri pekerjaannya. Menurut ketentuan baru ini (UU 851407), para napi hanya berada di penjara ketika mereka tidak terlibat dalam pekerjaan di luar penjara. Oleh karena itu, semi liberte lebih mempunyai ciri sebagai penahanan akhir minggu (week end detention). Bedanya, hari-hari di luar penjara padasemi liberte juga dihitung

${ }^{24}$ Lebih lengkapnya terkait semi liberte bisa dilihat pada karya G Dubost, "L'organisation Spatiale et Sociale de Muntiacus Reevesi Ogilby 1839 en Semi-Liberté." Mammalia 34, no. 3 (1970): h. 331-355. G Dubost, "Observations Ethologiques sur le Muntjak (Muntiacus mMuntjak Zimmermann 1780 et M. Reevesi Ogilby 1839) en Captivité et Semi-Liberté." Zeitschrift für Tierpsychologie 28, no. 4 (1971): h. 387-427. A. N. N. E. Monard ,"Causes et Conséquences du Départ des Jeunes Femelles de Leur Groupe Natal dans un Troupeau de Chevaux Camargue en Semi-Liberté." PhD diss., Rennes 1, 1992. 
sebagai hari-hari penahanan. Sementara itu di Portugal terdapat pengaturan sejak tahun 1983, UU setempat memberi peluang kepada hakim untuk menetapkan bahwa pidana sampai 3 bulan dapat dilaksanakan dalam bentuk "weekend detention" atau "semi detention" (Pasal 44 dan 45 PC-1983). Pasal 44 menyatakan bahwa pidana penjara dapat dikonversi menjadi "weekend detention". Apabila konversi pidana penjara pendek ke pidana denda atau "weekend detention" tidak dimungkinkan, dapat dipilih "semi detention". Bentuk pidana ini memberi kebebasan kepada napi untuk bebas di luar penjara, melakukan pekerjaan normalnya, atau pendidikannya. Semi detention ini harus dengan persetujuan terpidana (Pasal 45C). Seperti yang dikemukakan Barda Nawawi Arief, Pasal 44-45 di atas kemudian sudah berubah menjadi Pasal 45-46 dalam publikasi KUHP Portugal Oktober 2006. Semi Liberte dan Weekend-detention di Portugal hanya untuk pidana 3 bulan penjara, sedangkan di Perancis untuk pidana 6 bulan penjara/kurang.

2. Weekend-detention ${ }^{25}$ (hanya malam minggu masuk penjara). Ketentuannya hanya akhir minggu penjara, hari-hari di luar penjara tidak dihitung sebagai hari-hari penahanan di Portugal hanya untuk pidana 3 bulan penjara, di Perancis untuk pidana 6 bulan penjara/kurang;

3. Goodtime allowance ${ }^{26}$ (pengurangan masa pidana penjara karena melakukan pekerjaan dengan baik). Ketentuan semacam ini terdapat di negara Yunani, goodtime allowane-pengurangan masa pidana penjara dengan melakukan suatu pekerjaan (UU 1952)

a. Terpidana penjara lebih dari 6 bulan dapat mengurangi pidanannya dengan bekerja di luar, yaitu di suatu tempat yang disebut "penjara perkebunan/pertanian" ("farm prisons")

b. Pidananya akan dikurangi 2 hari untuk tiap hari kerja. Kemngkinan lain, pidananya akan dikurangi 1 1/2 hari untuk tiap hari kerja di dalam penjara.

c. Pengurangan pidana dinyatakan batal apabila napi berkelakuan

25 Barda Nawawi Arief, Kapita Selekta Hukum Pidana, h. 267.

${ }^{26}$ Barda Nawawi Arief, Kapita Selekta Hukum Pidana, h. 267. 
buruk (tidak disiplin) atau tidak melaksanakan pekerjaan dengan cara yang baik/patut. Jadi, pengurangan pidana karena bekerja baik inilah yang merupakan "pemberian penghargaan/upah" yang disebut dengan istilah "goodtime allowance" ("GA"). GA ini merupakan sarana individualisasi sanksi dan rehabilitasi narapidana. "GA" hanya mengurangi masa napi berada di penjara, tidak mengurangi masa/lamanya pidana itu sendiri.

4. Fragmentation of imprisonment (pelaksanaan pidana penjara yang dicicil); dalam hal ini, RUU KUHP memuat unsur ini, pada Pasal 73. Selain itu, aturan ini juga terdapat di dalam KUHP Albania (Chapter VII) berjudul "Alternative To Imprisonment" pada Pasal 58 ayat (1) dan (2), untuk pidana penjara maksimum 1 tahun pengadilan mempertimbangkan adanya keadaan keluarga, medis, jabatan/pekerjaan, atau keadaan sosial yang sangat gawat/genting, dapat menetapkan fragmentasi pelaksanaan pidana tidak kkurang dari 2 haru perminggu. Pelaksanaan fregmentasi pidana tersebut harus diselesaikan dalam waktu 3 tahun. Ketentuan di atas mirip dengan Article 132-27 KUHP Perancis yang menyatakan: "Apabila ada alasan-alasan pertimbangan sosial yang memaksa/mendesak, pengadilan boleh memutuskan bahwa pidana custodial satu tahun atau kurang untuk pelanggaran (misdemeanour) dilaksanakan secara angsuran dalam waktu tidak lebih dari 3 tahun. Angsuran/cicilan itu tidak boleh lebih pendek dari dua hari.

5. Parole (conditional release) merupakan alternatif peringanan dalam bentuk pelepasan bersyarat, cara ini bisa juga dilakukan untuk narapidana seumur hidup. Pengaturan ini terdapat dalam KUHP Albania, dalam Pasal 65, ada ketentuan pelepasan bersyarat (parole) untuk napi seumur hidup yang menyatakan:

a. Prinsipnya, napi seumur hidup tidak memperoleh parole.

b. Hanya untuk keadaan luar biasa (extra ordinary) diperbolehkan, yaitu apabila:

1) Telah menjalani pidana penjara tidak kurang dari 25 tahun;

2) Selama menjalani pidana berkelakuan baik (excellent behavior) dan tujuan pendidikan telah tercapai (the educational aim has been achieved). 


\section{Latar Belakang Ide Alternatif Keringanan Pidana Penjara dalam RUU KUHP}

Salah satu alasan atau latar belakang munculnya ide alternatif pidana penjara adalah banyaknya kritik dan ketidakpuasan terhadap pidana penjara. Menurut Barda Nawawi Arief, ${ }^{27}$ secara garis besar, kritik tersebut terdiri atas kritik ekstrem dan kritik moderat.

Pertama, kritik ekstrem. Kritik ekstrem menghendaki hapusnya sama sekali pidana penjara. Gerakan penghapusan pidana penjara (prison abolition) ini terlihat dengan adanya International Conference on Prison Abolition (ICOPA) yang diselenggarakan pertama kali pada Mei 1983 di Toronto, Kanada. Pada konferensi ke-3 tahun 1987 di Montreal, Kanada, istilah "prison abolition" telah diubah menjadi "penal abolition". Salah satu tokoh gerakan "prison abolition" ini adalah Herman Bianchi yang menyatakan "The institution of prison and imprisonment are to be for ever abolished entirely and totally. No trace should be lift of this darkside in human history" ("Lembaga penjara dan pidana penjara harus dihapuskan untuk selama-lamanya dan secara menyeluruh. Tidak sedikitpun (bekas) yang patut diambil dari sisi yang gelap dalam sejarah kemanusiaan ini”).

Jauh sebelum gerakan ICOPA, pendapat untuk menghapuskan pidana penjara di Indonesia telah dikemukakan oleh Hazairin, ejak tahun 1972 dalam tulisannya yang berjudul Negara Tanpa Penjara. Menurut Hazairin seperti dikutip oleh Barda Nawawi Arief, masyarakat tanpa penjara merupakan suatu ideal yang tinggi mutu filsafat dan keuntungannya, baik dilihat secara spiritual maupun secara materil.

Kedua, kritik moderat. ${ }^{28}$ Kritik moderat ini pada intinya masih mempertahankan pidana penjara, tetapi penggunaannya dibatasi. Pandangan moderat terhadap pidana penjara dapat dikelompokkan dalam tiga kritik, yaitu kritik dari sudut "strafmodus", dari sudut "straftmaat" dan dari sudut "stradsoort". Kritik dari sudut "strafmodus", Kritik ini melihat dari sudut pelaksanaan pidana penjara, jadi dari sudut sistem pembinaan/"treatment" dan kelembagaan/institusinya. Kritik dari sudut

\footnotetext{
${ }^{27}$ Barda Nawawi Arief, Kapita Selekta Hukum Pidana, h. 268.

${ }^{28}$ Barda Nawawi Arief, Kapita Selekta Hukum Pidana, h. 268.
} 
ini sudah cukup lama. Tokoh yang terkenal adalah John Howard (17261790) yang dikenal sebagai the founding father of prison reform. Kritik dari sudut straftmodus inilah yang memunculkan adanya Standard Minimum Rules (SMR) for the Treatment of Prisoners, hasil Kongres PBB) ke-1/1955 yang kemudian disetujui oleh Ecosoc pada 31 Juli 1957 (Resolusi PBB No. 663 C. XXIV). Sementara kritik dari sudut "strafmaat", kritik ini melihat dari sudut lamanya pidana penjara, khususnya ingin membatasi atau mengurangi penggunaan pidana penjara pendek. Terlihat dengan adanya rekomendasi Kongres PBB ke-2 Tahun 1960 di London yang antara lain, menyatakan penggunaan pidana penjara pendek secara luas tidak dikehendaki, penghapusan menyeluruh pidana penjara pendek tidaklah mungkin, pengurangan berangsur-angsur dengan meningkatkan bentuk-bentuk pengganti/alternatif, dalam hal pidana penjara pendek tidak dapat dihindari, pelaksanaannya harus terpisah/tersendiri dan pembinaannya harus konstruktif, pribadi dan dalam lembaga terbuka (open institution).

Resolusi ini jelas berkaitan erat dengan tujuan untuk menunjang pelaksanaan SMR for the Treatment of Prisoners. Untuk dapat menampung, mengawasi, dan membina para narapidana, maka jumlah narapidana tidak boleh melampaui kapasitas lembaga yang pada umumnya disebabkan oleh besarnya jumlah narapidana yang dijatuhi pidana pendek.

Kritik dari sudut "strafsoort,, ${ }^{29}$ ditujukan terhadap penggunaan atau penjatuhan pidana penjara dilihat sebagai "jenis pidana", yaitu adanya kecenderungan untuk mengurangi atau membatasi penjatuhan pidana penjara secara limitatif dan selektif. Kecenderungan menggunakan kebijakan "selektif dan limitatif" ini terlihat dari The First Offenders Act 1958 di Inggris yang melarang dijatuhkannya pidana penjara kepada "pelaku pertama/pemula" (first offender) dan pernyataan berbagai dokumen internasional, antara lain: ${ }^{30}$

1) Kongres PBB Ke-5 di Genewa. Dalam Kongres tersebut menyatakan: "As a matter of public policy, the use of imprisonment should be restriced

\footnotetext{
29 Barda Nawawi Arief, Kapita Selekta Hukum Pidana, h. 268.

${ }^{30}$ Barda Nawawi Arief, Kapita Selekta Hukum Pidana, h. 269.
} 
to those offenders who needed to be neutralized in the interest of public safety and for the protection of society."

2) Kongres PBB ke-6 1980 di Caracas (Venezuela). Dalam kongres tersebut menyatakan: "Believing that tendency observable in many countries to avoid imposing prison sentences as far as possible can be taken further without undue risk to public policy". (Salah satu pertimbangan resolusi ke-8).

3) Kongres PBB ke-7 1985 di Milan (Italia). Dalam resolusi ke-2 mengenai "Reduction of the Prison Population Alternative to imprisonment, and Social integration of Offenders", antara lain, dipertimbangkan bahwa hasil-hasil atau studi penelitian menunjukkan bahwa di banyak negara meningkatnya jumlah dan lamanya pidana penjara tidak mempunyai pengaruh yang kuat terhadap pencegahan kejahatan dan pencegahan itu lebih dapat dicapai secara efektif dengan pendeteksian kejahatan secara pasti dan cepat, bahwa hasilhasil kongres yang lalu dan Resolusi Ecosoc No.46/1984 tanggal 25 Mei 1984 mendorong untuk meningkatkan penggunaan sanksi-sanksi yang non-custodial. Berdasarkan pertimbangan tersebut, Resolusi ke-2 menyatakan, antara lain: agar negara anggota meningkatkan usaha untuk mengurangi akibat-akibat negatif dari pidana penjara. Negara anggota harus mengefektifkan penelitian-penelitian mengenai sanksi-sanksi non-custodial untuk mengurangi populasi penjara. Pidana penjara hendaknya hanya dijatuhkan sebagai suatu sanksi dari upaya terakhir dengan mempertimbangkan sifat dan bobot keseriusan tindak pidana, kondisi sosial yang relevan menurut hukum dan keadaan lainnya yang bersifat pribadi dari pelaku ${ }^{31}$

Pada prinsipnya, pidana penjara jangan dikenakan kepada pelanggaranpelanggaran ringan (petty offenders) apabila sanksi non-custodial digunakan, pada prinsipnya sanksi-sanksi tersebut harus digunakan sebagai bentuk sanksi yang benar-benar merupakan alternatif dari pidana penjara dan bukan sebagai bentuk sanksi "di samping" pidana penjara. Masyarakat umum harus diberi informasi yang lebih baik mengenai keuntungan-

${ }^{31}$ Barda Nawawi Arief, Kapita Selekta Hukum Pidana, h. 269. 
keuntungan dan pentingnya sanksi-sanksi non-custodial dibandingkan dengan pidana penjara. Menghindari sejauh mungkin penggunaan pidana penjara sebagai pengganti pidana denda yang tidak dibayar, khususnya dengan menjamin/memastikan bahwa:

(1) Pidana denda dijatuhkan sesuai dengan kemampuan membayar dari pelanggar;

(2) Sebelum seseorang dipenjarakan karena tidak membayar denda, semua keadaan dipertimbangkan sepenuhnya; dan

(3) Di samping pidana oenjara, sanksi non-custodial dapat dikenakan untuk memohon kepada Komite Pencegahan dan Pengendalian Kejahatan (Committee on Crime Prevention and Control) untuk mendorong perhimpunan bangsa-bangsa regional dan lembagalembaga interregional agar mengembangkan sanksi-sanksi noncustodial yang efektif dan tindakan-tindakan pengintegrasian sosial bagi para pelanggar serta pembatasan penggunaan pidana penjara.

4) SMR-JJ (The Beijing Rules), Resolusi MU PBB 40/33 Tahun 1985. Dalam resolusi tersebut, antara lain menyatakan: ${ }^{32}$

Rule 17.1.:

Pembatasan kebebasan/kemerdekaan pribadi anak (restrictions on the personal liberty of the juvenile) hanya dikenakan setelah pertimbangan yang hati-hati dan dibatasi seminimal mungkin.

Perampasan kemerdekaan pribadi (deprivation of personal liberty) jangan dikenakan kecuali anak melakukan perbuatan serius atau terus-menerus melakukan tindak pidana serius dan kecuali tidak ada bentuk respons/sanksi lain yang lebih cepat.

Rule 19.1.:

"Penempatan seorang anak dalam lembaga harus selalu ditetapkan sebagai upaya terakhir dan untuk jangka waktu minimal yang diperlukan”.

5) UN SMR for Non-Custodial Measures (The Tokyo Rules), Resolusi MU PBB 45/110 tanggal 14 Desember 1990. Dalam

32 Barda Nawawi Arief, Kapita Selekta Hukum Pidana, h. 269. 
pertimbangannya menyatakan, antara lain: Pembatasan kemerdekaan hanya dapat dibenarkan dilihat dari sudut keamanan masyarakat (public safety), pencegahan kejahatan (crime prevention), pembalasan yang adul dan penangkalan (just retribution and deterrence), dan tujuan utama dari sistem peradilan pidana adalah "reintegrasi pelaku tindak pidana ke dalam masyarakat" (reintegration of offender into society). Meningkatnya populasi penjara dan semakin padatnya penjara merupakan faktor yang menimbulkan kesulitan untuk diterapkannya SMR for the Treatment of Prisoners.

Resolusi PBB 45/133 Tahun 1990. "UN Rules for the Protection of Juveniles Deprived of their Liberty" Resolusi tersebut menyatakan antara lain: Pidana penjara harus digunakan sebagai upaya terakhir ("imprisonment should be used as a last resort"). Perampasan kemerdekaan anak harus ditetapkan sebagai upaya terakhir dan untuk jangka waktu minimal yang diperlukan serta dibatasi untuk kasus-kasus yang luar biasa/eksepsional.

Uraian di atas, dapatlah dikatakan bahwa upaya mencari alternatif pidana penjara merupakan perwujudan dari kebijakan selektif dan limitatif dalam menggunakan pidana penjara. Kebijakan selektif dan limitatif bukan persetujuan menghapuskan pidana penjara secara total, melainkan sekedar upaya menghindari sisi negatif dan kelemahan/kekurangan dari pidana penjara. ${ }^{33}$

Latar belakang perlunya dikembangkan alternatif pidana penjara terungkap pula dalam dokumen PBB berjudul "Custodial and NonCustodial Measures, Alternative to Incarceration, UN New York, 2006. Dalam dokumen itu antara lain dinyatakan bahwa jumlah napi di seluruh dunia semakin meningkat dan memberi beban finansial yang sangat besar bagi pemerintah. Sementara itu, ada pengakuan bahwa pidana penjara tidak dapat mencapai beberapa tujuannya yang sangat penting di samping juga membahayakan/merugikan terpidana beserta keluarganya dan dalam waktu panjang merugikan masyarakat. Penjara mempunyai banyak tujuan, antara lain, melakukan rehabilitasi dan memberi keamanan

${ }^{33}$ Barda Nawawi Arief, Kapita Selekta Hukum Pidana, h. 270. 
bagi masyarakat. Namun, kenyataan menunjukkan bahwa penjara tidak hanya jarang dapat merehabilitasi napi, tetapi juga cenderung membuat individu lebih jahat, mengulangi lagi perbuatannya, dan kembali ke penjara, yang berarti sama sekali tidak mengurangi kepadatan/kelebihan penjara atau tidak membangun masyarakat yang lebih aman. Kebanyakan napi di seluruh dunia berasal dari latar belakang ekonomi-sosial yang lemah/tidak menguntungkan. Kemiskinan, pengangguran, ketiadaan rumah, broken home, problem kejiwaan/sakit jiwa, penyalahgunaan alcohol dan obat-obatan, dan KDRT, merupakan realitas yang dijumpai dalam kehidupan para napi. Kebanyakan napi berada di penjara karena delik ringan dan bukan delik kekerasan (non-violent or minor offences). Dengan menggunakan penjara sebagai jawabannya untuk orang-orang seperti itu, tidak hanya merupakan masalah keamanan masyarakat, tetapi juga mengabadikan siklus pemiskinan (the cycle of impoverishment), kehilangan pekerjaan, memperlemah kesempatan kerja, merusak silaturahmi memperburuk penyakit jiwa, dan meningkatkan penyalahgunaan obat-obatan. Juga banyak risiko kesehatan dari kepadatan penjara, termasuk penyebaran penyakit infeksi, seperti TBC dan HIV. Di banyak negara, kekerasan menjadi unsur umum dalam kehidupan penjara, khususnya apabila ada overkapasitas/overcrowding. ${ }^{34}$

Overcrowding dapat dikurangi dengan membangun penjara baru atau mengurangi jumlah penghuninya. Namun, praktik menunjukkan, upaya melalui pembangunan penjara-penjara baru bukan merupakan solusi yang berkelanjutan. Bahkan sejumlah negara Eropa yang telah menaikkan/memperluas program pembangunan penjara, hanya menemukan jumlah napi mereka meningkat seiring dengan meningkatnya kapasitas yang diperolehnya dari perkebunan-perkebunan penjara. Tambahan pula, membangun penjara baru dan memeliharanya dan memeliharanya sangatlah mahal dengan menekan sumber-sumber lainnya. Sementara itu beberapa instrumen internasional merekomendasikan rasionalisasi kebijakan pemidanaan, termasuk penggunaan "alternative to prison" dengan berusaha mengurangi jumlah napi yang dikenakan pidana penjara dalam waktu lama.

${ }^{34}$ Barda Nawawi Arief, Kapita Selekta Hukum Pidana, h. 271. 
Akan tetapi tujuan "alternative to prison" tidaklah semata-mata untuk memecahkan problem "overcrowding in prisons". Penggunaan alternatif yang lebih luas merupakan refleksi dari perubahan fundamental dalam melakukan pendekatan terhadap kejahatan, pelaku, dan tempatnya di dalam masyarakat (a fundamental change in the approach to crime, offenders, and their place in society), dan perubahan fokus perhatian tindakantindakan penitensier dari "pidana dan isolasi" ke "keadilan restoratif dan reintegrasi" (changing the focus of penitentiary measures from punishment and isolation, to restorative justice and reintegration). ${ }^{35}$

Apabila hal itu semua dibarengi dengan dukungan yang memadai untuk pelanggar/pelaku, hal itu membantu kebanyakan anggota masyarakat mengarah pada kehidupan tanpa kembali terjerumus ke pola perbuatan criminal. Jadi, implementasi sanksi pidana di dalam masyarakat (penal sanctions within the community) lebih baik daripada melalui proses isolasi dan dalam jangka panjang menawarkan perlindungan masyarakat yang lebih baik.

Ada juga alasan ekonomis untuk keuntungan alternatif pidana penjara. Di masyarakat Barat, pengawasan pelaku dalam sistem probation umumnya lebih murah daripada merawat/memelihara napi. Dalam konteks ini, perlu ditekankan bahwa alternatif yang ada (yang mereka miliki) sangat kecil efeknya pada jumlah populasi penjara. Agar tujuan mengurangi jumlah napi tercapai, pembaharuan perundang-undangan pidana yang komprehensif perlu dilakukan dan praktik pemidanaan perlu diubah.

Walaupun kemungkinan banyak keuntungan dari alternatif pidana penjara, Tokyo Rules sendiri (di dalam "commentary"-nya) pernah menyatakan kekhawatiran dan peringatan akan bahaya potensial dari tindakan non custodial yang mungkin akan membawa akibat yang tidak diinginkan. Seperti dinyatakan: ${ }^{36}$

"Despite the obvious advantage of non-custodial measures, reforms intended to promote the use of such measures contain potential dangers and may lead

${ }^{35}$ Barda Nawawi Arief, Kapita Selekta Hukum Pidana, h. 271.

${ }^{36}$ Barda Nawawi Arief, Kapita Selekta Hukum Pidana, h. 272. 
to unintended consequences. For example, the use of non-custodial measures may be increased, not at the expence of imprisonment but at the expense of other less onerous penalties. This may lead to an increase in the total use of penal measures in society, an increase that cannot be justified by a reference to a worsened crime situatuin. At the same time, there may be no reduction in the use of imprisonment. This has been termed the net widening effect."

("Meskipun ada keuntungan yang jelas dari tindakan noncustodial, namun mengandung bahaya potensial dan akibat-akibat yang tidak diinginkan. Misalnya, meningkatnya penggunaan tindakan-tindakan itu bukan untuk mengorbankan/mengurangi pidana penjara, melainkan untuk pidana lainnya yang kurang berat. Hal ini dapat mengingkatkan jumlah penggunaan tindakan pidana dalam masyarakat yang tidak dapat dibenarkan dibandingkan dengan situasi kejahatan yang semakin memburuk. Pada saat yang sama, berarti tidak ada pengurangan dalam penggunaan pidana penjara. Inilah yang disebut 'efek bersih yang meluas' (the net-widening effect').

\section{Analisis Alternatif Keringanan Pada Pelaksanaan Pidana Penjara dalam RKHUP Ditinjau dari Konsep Maqâshid al-Syarî'ah}

Secara etimologis, maqâshid al-syarîah terdiri dari dua suku kata yakni maqâshid dan syarîah. Maqâshid berasal dari kata qasada yang berarti, bermaksud, berkehendak, atau menuju sesuatu, Sedangkan syarîah berarti jalan yang jelas menuju sumber air, atau hukum, peraturan. Syarîa $a$ bisa juga diartikan sebagai agama. Menurut Ibnu Qayyim, seperti dalam M. Yalis, syarîah adalah: ${ }^{37}$

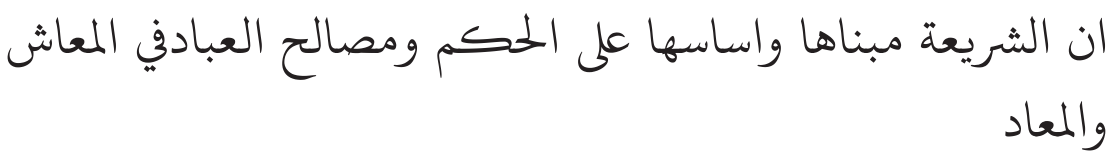

Sesungguhnya syariat itu pondasi dan azasnya ialah hikmah dan kemaslhatan hamba baik dalam kehidupan dunia maupun maupun dalam kehidupan akhirat.

Menurut al-Raisuni, maqâshid al-syarîah adalah tujuan-tujuan yang diletakkan oleh syariah untuk diwujudkan demi kemaslahatan hamba

${ }^{37}$ M. Yalis Shokhib, "Kontektualisasi Perkawinan dalam Tinjauan Maqasid Syariah.” AlAdalah: Jurnal Syariah dan Hukum Islam 2, no. 1 (2017), h. 18. 
manusia. Kemashlahatan yang menjadi tujuan syariat ini dibatasi dalam lima hal, agama, jiwa, akal, keturunan dan harta. Setiap hal yang mengandung penjagaaan atas lima hal ini disebut maslahah dan setiap hal yang membuat hilangnya lima hal ini disebut mafsadah. ${ }^{38}$ Dengan kata lain, maqâshid al-syarîah berarti kandungan nilai yang menjadi tujuan pensyariatan hukum. ${ }^{39}$

Sementara itu, al-Syatibi berpendapat bahwa maqâshid al-syarîah adalah maslahah atau kebaikan dan kesejahteraan umat manusia. Umat manusia ini diartikan secara umum tidak hanya umat Islam saja, sebagaimana penjelasan dalam Alquran:

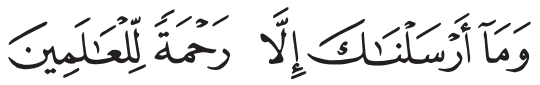

"Dan tidaklah Kami mengutus kamu, melainkan untuk (menjadi) rahmat bagi semesta alam.” (Q.s. al-Anbiya [21]: 107)

Beberapa definisi di atas dianggap cukup mewakili bagi kita untuk menyimpulkan bahwa maqâshid al-syarîah adalah tujuan ditetapkannya hukum-hukum Allah bagi seluruh hamba-Nya, di mana tujuan tersebut tidak lain untuk kebaikan dan kemaslahatan mereka dalam menjalankan kehidupan duniawi dan ukhrawi kelak.

Untuk menuju kepada maqâshid al-syarîah tersebut, Hujjatul Islam Abû al-Hamid al-Ghazali seperti dikutip Ahmad Syafiq, ${ }^{40}$ telah membuat satu perbahasan khusus yang menjelaskan tentang maslahah sebagai asal yang tidak jelas membaginya kepada tiga (3) tingkatan yang kemudiannya dirinci oleh Imam al-Syathibi. Pertama, dharûriyat (primer) artinya harus ada demi kemaslahatan hamba, yang jika tidak ada, akan menimbulkan kerusakan, misalnya rukun Islam. Bila tingkat kebutuhan ini tidak terpenuhi, akan terancam keselamatan umat manusia baik di dunia maupun di akhirat. Untuk memelihara kelima unsur pokok (memelihara

${ }^{38}$ Zul Anwar Ajim Harahap, "Konsep Maqasid Al-Syariah Sebagai Dasar Penetapan Dan Penerapannya Dalam Hukum Islam Menurut 'Izzuddin Bin 'Abd Al-Salam (W.660 H)", Tazkir 9, ( Juli-Desember 2014), h. 180.

${ }^{39}$ Ghofar Shidiq, "Teori Maqashid al-Syari'ah dalam Hukum Islam." Majalah Ilmiah Sultan Agung 44, no. 118 (2018), h. 118

${ }^{40}$ Ahmad Syafiq, "Rekonstruksi Pemidanaan dalam Hukum Pidana Islam (Perspektif Filsafat Hukum”), Jurnal Pembaharuan Hukum I, no. 2 (Mei - Agustus 2014), h. 183. 
agama, jiwa, keturunan, harta dan akal) inilah syariat Islam diturunkan. Semua perintah dan larangan syariat bermuara kepada pemeliharaan lima unsur pokok ini. Dharûriyat dijelaskan dengan lebih rinci mencakup lima tujuan (al-kulliyyat al-khamsah), yaitu menjaga agama (hifdz aldîn), menjaga jiwa (hifdz al-nafs), menjaga akal (hifdz al-'aql), menjaga keturunan (hifdz al-nasl), dan menjaga harta (hifdz al-mal). Sehingga tujuan dari maqâshid al-syarî̀ah akan tercapai jika terpenuhinya penjagaan kelima unsur yang telah disebutkan di atas.

Kedua, hajiyat (sekunder) maksudnya sesuatu yang diperlukan untuk menghilangkan kesempitan, bila tidak diiwujudkan tidak sampai mengancam keselamatan, namun manusia akan mengalami kesulitan. Syariat Islam menghilangkan segala kesulitan ini. Adanya hukum rukhsah (keringanan) merupakan bukti kepedulian syariat Islam terhadap kebutuhan hajjiyat, seperti rukhsah (keringanan) tidak berpuasa bagi orang sakit. Dalam lapangan uqûbat (sanksi pidana), Islam mensyariatkan diat bagi pembunuh tidak sengaja, dan menangguhkan hukuman potong tangan bagi pencuri yang terdesak menyelamatkan jiwanya dari kelaparan. Sebab suatu kesempitan menimbulkan keringanan dalam syariat Islam, sebagaimana diisyaratkan dalam Q.s. al-Maidah [5]: 6 yang berbunyi:

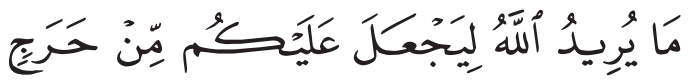

'... Allah tidak ingin menyulitkan kamu...'

Ketiga, tahsinniyat (suplementer) artinya sesuatu yang diambil untuk kebaikan kehidupan dan menghindarkan keburukan, mengambil apa yang sesuai dengan kebiasaan (adat) yang paling baik dan menghindari cara-cara yang tidak disukai oleh orang-orang yang bijaksana, semisal akhlak yang mulia, menghilangkan najis, dan menutup aurat. Kebutuhan tahsiniyat, merupakan tingkat kebutuhan yang apabila tidak terpenuhi tidak mengancam eksistensi salah satu dari unsur pokok di atas dan tidak pula menimbulkan kesulitan. Tingkat kebutuhan ini sebagai kebutuhan pelengkap. ${ }^{41}$

${ }^{41}$ La Jamaa, "Dimensi Ilahi dan Dimensi Insani dalam Maqashid al-Syari'ah", Jurnal Ilmu Syariah dan Hukum 45, no.2, (Juli-Desember 2011), h. 1260. 
Para ulama telah menyatakan, bahwa kelima prinsip ini telah diterima secara universal. ${ }^{42}$ Dalam menganalisis tujuan-tujuan kewajiban syariat ditemukan bahwa syariat juga memandang kelima hal tersebut sebagai sesuatu yang mesti dilakukan. Kewajiban-kewajiban syariat bisa dibagi dari sudut pandang cara-cara perlindungan yang positif dan preventif menjadi dua kelompok. Termasuk dalam kelompok cara yang positif adalah ibadah, adat kebiasaan dan muamalah. Sedangkan yang termasuk dalam kelompok preventif adalah jinâyat (hukum pidana).

Mengacu kebutuhan masyarakat tersebut, dalam RKUHP tersusun begitu sistematis konsep-konsep yang diharapkan dapat sesuai dengan kondisi masyarakat Indonesia dan sesuai dengan tujuan penegakan hukum dengan nilai-nilai khas Pancasila. Salah satunya adalah tercermin dengan adanya alternatif keringanan pada pelaksanaan pidana penjara. Dengan salah satu pembaharuan yang dikonsepkan ini diharapkan dapat mewujudkan tujuan hukum dan konsep restorative justice yang diidamidamkan.

Agama Islam adalah cara hidup yang paling sempurna yang membawa rahmatan lil 'alamîn (kasih sayang bagi seluruh alam semesta). Islam terus hidup dan senantiasa sesuai dengan perkembangan zaman dan segala keadaan yang dihadapi oleh umatnya, elastik dan tidak stagnan. Allah Maha Bijaksana (al-Hakîm), di mana Dia tidak menciptakan sesuai dengan main-main atau penuh dengan kebathilan. Dia tidak akan membuat sesuatu hukum untuk siasia, karena Allah Swt, sama sekali tidak memerlukan kepada hamba-hamba-Nya. Segala perintah, larangan penghalalan, pengharaman, atau diperbolehkan semata-mata hanya untuk kemaslahatan manusia agar mereka jauh dari kesesatan dan kerusakan.

Hal tersebut diatas jika dalam pemikir Islam terkenal dengan istilah maqâshid al-syarîah yang dimaksudkan oleh Imam Syatibi. Maqâshid atau Maslahat Dharuriyyat adalah sesuatu yang mesti adanya demi terwujudnnya kemaslahatan agama dan dunia. Apabila hal ini tidak ada, maka akan menimbulkan kerusakan bahkan hilangnya hidup dan

${ }^{42}$ La Jamaa, "Dimensi Ilahi dan Dimensi Insani dalam Maqashid al-Syariah", h. 1257. 
kehidupan seperti makan, minum, salat, shaum dan ibadah lainnya, termasuk maslahat atau maqâshid dharûriyyat ini ada lima yaitu agama (al-dîn), jiwa (al-nafs), keturunan (al-nasl), harta (al-mâl) dan akal (al-aql).43

Pasal 73 RKUHP merupakan terobosan baru dalam hal pelaksanaan pidana penjara. Pasal tersebut mengakomodir cita-cita alternatif pelaksanaan pidana penjara, hakim diberikan wewenang untuk diperbolehkan menjatuhkan putusan pelaksanaan pidana dengan cara diangsur dengan beberapa ketentuan, di antaranya:

a. Penjatuhan pidana penjara 1 tahun atau kurang dari 1 tahun

b. Hanya dapat diberikan apabila ada kondisi yang sangat gawat atau menimbulkan akibat lain yang sangat mengkhawatirkan apabila terdakwa menjalani pidananya secara berturut-turut.

c. dapat dilaksanakan paling lama 2 (dua) hari dalam 1 (satu) minggu atau 10 (sepuluh) hari dalam sebulan dengan ketentuan jumlah atau lama angsuran tidak melebihi 3 (tiga) tahun

Berikut analisis ketentuan pelaksanaan alternatif pidana penjara ditinjau dari perspektif maqâshid al-syarî̀ah Imam Syatibi:

1. Hifdz al-dîn (menjaga agama). Dalam menjalani alternatif hukuman pelaksanaan pidana penjara dengan jalan dicicil, baik penegak hukum, korban maupun keluarga korban, pelaku maupun keluarga pelaku tetaplah telah menegakan ataupun menjalankan hukuman yang sesuai dengan tujuan dari hukum itu sendiri. Jika masing-masing telah melaksanakan hak dan kewajibannya, hal tersebut memiliki kesesuaian dengan tujuan agama dan menjaga agama. Mengenai keadilan, banyak sekali ayat dan hadis Nabi yang memerintahkan agar seorang muslim menegakkan keadilan sekalipun terhadap keluarga dan karib kerabat terdekat. Salah satu firman Allah Swt megenai asas keadilan hukum Islam adalah: ${ }^{44}$

${ }^{43}$ Abdurrahman Kasdi, "Maqasyid Syariah Perspektif Pemikiran Imam Syatibi dalam Kitab Al-Muwafaqat”, Jurnal Yudisia, (2014), h. 56

${ }^{44}$ M. Nurul Irfan, Hukum Pidana Islam (Jakarta: Amzah, 2016), h. 12. 


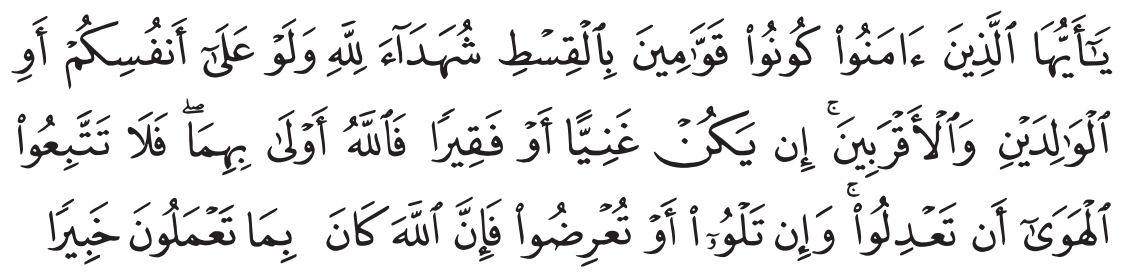

Wahai orang-orang beriman! Jadilah kamu penegak keadilan, menjadi saksi karena Allah, walaupun terhadap dirimu sendiri atau terhadap ibu bapak dan kaum kerabatmu. Jika ia (yang terdakwa) kaya ataupun miskin, maka Allah lebih tahu kemaslahatan (kebaikannya). Maka janganlah kamu mengikuti hawa nafsu karena ingin menyimpang dari kebenaran. Dan jika kamu memutarbalikkan (kata-kata) atau enggan menjadi saksi, maka ketahuilah Allah Maha teliti terhadap segala apa yang kamu kerjakan. (Q.s. al-Nisa [4]: 135).

Selain dalam hal menjunjung keadilan sesuai yang disyariatkan oleh agama, pelaksanaan pidana penjara dengan sistem diangsur juga sangat memungkinkan seseorang dalam menjaga agamanya, melakukan peribadatan dengan lebih leluasa tanpa ditahan di dalam kompleks penjara dengan kesan 'perampasan kemerdekaan'.

a. Memelihara agama dalam peringkat dharûriyat adalah memelihara dan melaksanakan kewajiban agama yang termasuk peringkat primer, misalnya dilarangnya perilaku yang dapat menistakan agama lain, merusak simbol-simbol lain dan sebagainya. Ketika ini di abaikan maka eksistensi agama akan terancam dan bahkan hancur.

b. Memelihara agama dalam peringkat hajiyyat adalah melaksanakan ketentuan agama, dengan maksud menghindari kesulitan. Contohnya adalah menumbuhkan sikap toleransi beragama, membumikan makna dari ajaran rahmatan lil'alamîn dan sebagainya. Tatkala ketentuan ini tidak dilaksanakan, tidak akan mengancam eksistensi agama, hanya saja akan mempersulit orang yang melakukannya.

c. Memelihara agama dalam peringkat tahsîniyyat adalah mengikuti petunjuk agama guna menjunjung tinggi martabat manusia, sekaligus melengkapi pelaksanaan kewajiban terhadap Tuhan. 
Misalnya, bergaul yang baik dengan orang-orang yang berbeda. Jika ketentuan ini tidak memungkinkan untuk dilaksanakan, maka tidak akan mengancam eksistensi agama ataupun menyulitkan orang yang melaksanakannya hanya saja kurang elok. Karena aktivitas tahsîniyyat berkaitan erat dengan al-akhlâk al-karimah (perilaku yang terpuji).

2. Hifdz a-Nafs (menjaga jiwa). Pelaksanaan hukuman alternatif dalam pelaksanaan pidana penjara, terlebih bagi pelaku memiliki efek yang sangat meringankan, terlebih jika ia merupakan tulang punggung keluarga atau pelaku dalam kondisi darurat yang menurut hakim memenuhi kriteria akan diberikannya alternatif ini. Pelaku tetap dapat melindungi keluarganya. Tidak hanya pelaku saja, korban dan ataupun keluarga korban serta penegak hukum dapat tetap melindungi kelangsungan hidup dirinya dan atau keluarganya. Dalam menetapkan jarimah ta'zîr, prinsip utama uang menjadi acuan penguasa adalah menjaga kepentingan umum dan melindungi setiap anggota masyarakat dari kemudharotan (bahaya). Di samping itu, penegakkan jarîmah ta'zîr harus sesuai dengan prinsip syar'i. ${ }^{45}$ Dalam Islam, sumber hukum bersumber dari Allah Swt dan Rasul-Nya, serta dari ijtihad para ulama (ahl ijtihâd). Tujuan hukum Islam itu sendiri adalah kemaslahatan umat. Islam yang memiliki ajaran yang sempurna dan universal juga mengandung ajaran tentang hukum pidana yang dalam hal ini dapat diistilahkan dengan jinâyah, atau sebagian ulama mengistilahkan dengan sebutan jarîmah. Jinâyah adalah suatu nama untuk perbuatan atau tindakan pidana yang dilakukan seseorang yang yang dilarang Syara', baik itu perbuatan atas jiwa, harta atau selain jiwa dan harta. Jarimah adalah segala larangan-larangan yang haram karena dilarang oleh Allah Swt dan diancam dengan hukuman baik had ataupun ta'zîr. Agama jelas merupakan kebutuhan bagi manusia yang perlu dipelihara, dijaga dan direalisasikan oleh manusia.

${ }^{45}$ Lihat selengkapnya Azhari Akmal Tarigan. "Ta'zir dan Kewenangan Pemerintah dalam Penerapannya." AHKAM: Jurnal Ilmu Syariah 17, no. 1 (2017). 
3. Hifdz al-Aql (menjaga akal). Pelaksanaan alternatif pidana penjara ini juga akan menjaga akal karna dalam kehidupan positif yang dijalani memerlukan akal positif yang berasal dari lingkungan serta motivasi hidup yang positif pula. Selain itu, alternatif pelaksanaan hukuman ini dapat menjaga akal manusia terutama jika pelaku tindak pidana ini merupakan mahasiswa, pelajar maupun ahli pendidikan atau bahkan kepala keluarga yang menjadi tumpuan nafkah bagi keluarga yang anggota keluarganya masih menempuh pendidikan. Mengingat bahwa sarana untuk menjaga akal ialah ilmu. Kalimat wahyu pertama kali yang sampai kepada Rasulullah dan menyentuh telinga beliau ialah kalimat iqra' (bacalah!), setelah itu kalimat:

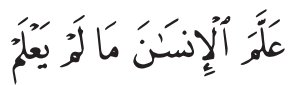

"(Dia mengajarkan kepada manusia apa yang tidak diketahuinya". (Al-Alaq [96]: 5).

Karena membaca merupakan jalan mendapatkan ilmu, meskipun bukan jalan satu-satunya, akan tetapi dia merupakan jalan terpenting. Dalam nash Al-Qur'an yang lain, Allah berfirman,

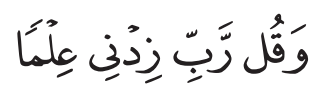

"(Dan katakanlah: "Ya Rabbku, tambahkanlah kepadaku ilmu pengetahuan" (Thaha [20]: 114).

Akan tetapi ilmu ini wajib diiringi dengan amal perbuatan. Ilmu bukan sekedar untuk diketahui, namun dengan ilmu agar bertakwa, beramal saleh, serta menjauhan diri dari perbuatan maksiat dengan landasan takwa kepada Allah Swt. Karenanya dalam firman Allah, surat al-Maidah ayat 91 disebutkan:

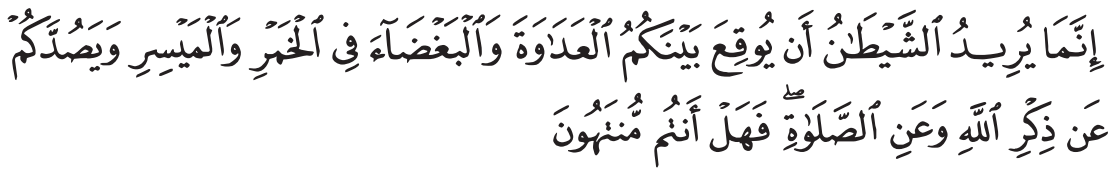

"Sesungguhnya setan itu bermaksud hendak menimbulkan permusuhan dan kebencian di antara kamu, dan berjudi itu menghalangi kamu dari mengingat Allah dan salat, maka berhentilah kamu (dari mengerjakan pekerjaan itu)". 
Inti dari maqâshid al-syarîah adalah untuk mencapai kemaslahatan umat yang sebesar-besarnya, karena tujuan penetapan hukum dalam Islam adalah untuk menciptakan kemaslahatan dalam rangka memelihara tujuan-tujuan syara'.

4. Hifdz al-Nasl (menjaga keturunan). Alternatif pemidanaan ini dapat berdampak baik terutama bagi pelaku, karena ia tetap dapat memberi penghidupan yang baik bagi dirinya, maupun keluarga yang tentunya juga bagi keberlangsungan garis keturunannya. Hal ini merupakan salah satu tujuan dari menjaga keturunan, yaitu kewajiban memelihara dan memberikan nafkah kepada anak, termasuk kewajiban memperhatikan pendidikan anak. Secara wajar, kebebasan yang dimiliki seseorang pasti dapat menjadikannya lebih fokus dalam menjaga keturunan.

Hal ini juga merupakan salah satu upaya regenerasi manusia yang disyari'atkan dalam Islam. Tentu yang diharapkan dalam Islam adalah keturunan yang bermartabat, yang dilahirkan dengan dianugrahi sebesar-besarnya manfaat untuk semua makhluk. Memelihara keturunan ini sebagian ulama ada juga yang menyebutnya dengan memelihara kehormatan. Dengan memiliki kebebasan walaupun terbatas, kehidupan dapat berjalan dan juga dapat mengajarkan kepada anak pentingnya memiliki akhlak yang baik. Sekalipun missal tidak dapat melakukannya sendiri, dengan kebebasan yang dimiliki maka akan membuka peluang untuk tetap bekerja dan menyediakan pendidikan bagi anaknya dengan baik. Hal ini sebagaimana yang disabdakan Rasulullah Saw, yang artinya "ajarilah anak-anakmu (akblak yang mulia), karena sesungguhnya anak-anakmu akan hidup di suatu zaman yang berbeda dengan zamanmu."

Perintah tersebut seyogyanya dimaknai bahwa orang tua harus mampu dimaknai bahwa orang tua memiliki keharusan untuk mendidik anak keturunannya dengan pengetahuan agama yang cukup, khususnya pembekalan akhlak yang mulia, dengan tidak mengabaikan aspek pendidikan lainnya seperti pendidikan ekonomi, teknologi, ilmu pengetahuan alam dan sebagainya 
5. Hifdz al-Mâl (menjaga harta). Dengan adanya alternatif yang pada dasarnya merupakan peringanan, akan menjaga pelaku dan korban maupun keluarganya tetap melanjutkan kegiatannya sehari-hari, adapun batasan tidak dilakukan untuk sepenuhnya merampas hak kemerdekaannya dan merubah siklus kehidupannya maupun keluarga secara total. Terutama dalam kaitannya dengan mata pencaharian dan keberlangsungan kehidupannya dari proses ekonomi. Terlebih jika pelaku memiliki posis penting di dalam lingkungan masyarakat yang ternyata memiliki tingkat ketergantungan ekonomi yang cukup tinggi dengannya. Secara tegas Islam mengakui adanya hak milik pribadi maupun kelompok. Harta benda yang dapat dimiliki dan ditransaksikan hanyalah yang diakui pemiliknya menurut syari'ah. Maka, menjadi haram hukumnya menguasai dan menjual-belikan harta milik orang lain atau barang curian dan segala jenis barang yang diperoleh secara batil maupun karena memang dzatnya sendiri yang secara syari'ah diharamkan. ${ }^{46}$

Menurut Dwidja, jika pidana penjara diperlukan untuk perlindungan masyarakat dari perilaku antisosial, maka penggunaanya perlu dibatasi dalam rangka mengurangi kritik-kritik terhadap pidana penjara. Pembatasan terhadap pidana penjara merupakan kritik yang moderat dalam arti pidana penjara masih diperlukan, namun dengan tetap memperhatikan strafmaat dan strafsoort. Strafmodus, dilihat dari sudut pelaksanaan pidana penjara, apakah sistem pembinaan oleh lembaga berjalan sesuai dengan harapan. Strafmaat, dilihat dari sudut lamanya pidana penjara, terutama penggunaan pidana penjara singkat (pendek), sedangkan strafsoort ditujukan terhadap penggunaan atau penjatuhan pidana penjara dilihat sebagai jenis pidana, yaitu adanya kecenderungan untuk mengurangi atau membatasi penjatuhan pidana penjara secara limitatif dan selektif. ${ }^{47}$ Penjara yang dilakukan secara limitatif dan selektif harus memperhatikan strafmodus, strafmaat, dan strafsoort di atas.

${ }^{46}$ Hamka Haq, Islam Rahmat untuk Bangsa (Jakarta: Wahana Semesta Intermedia, 2009), h. 295.

${ }^{47}$ Dwidja Priyatno, Sistem Pelaksanaan Pidana Penjara di Indonesia (Bandung: Refika Aditama, 2006), h. 84-85. 


\section{Penutup}

Pembahasan di atas, dapatlah diambil kesimpulan bahwa adanya alternatif keringanan pidana penjara dilatarbelakangi beberapa hal. Pertama, oleh banyaknya kritik dan ketidakpuasan terhadap pidana penjara. Secara garis besar, kritik tersebut terdiri atas kritik ekstrem dan kritik moderat. Kritik ekstrem ini menghendaki hapusnya sama sekali pidana penjara. Sementara itu kelompok yang masih ingin mempertahankan pidana penjara, tetapi penggunaannya dibatasi tergolong dalam kritik moderat. Pandangan moderat terhadap pidana penjara dapat dikelompokkan dalam tiga kritik, yaitu kritik dari sudut "strafmodus", dari sudut "straftmaat" dan dari sudut "stradsoort". Kedua, jumlah napi di seluruh dunia-termasuk di Indonesia, semakin meningkat dan memberi beban finansial yang sangat besar bagi pemerintah.

Kenyataan menunjukkan bahwa penjara tidak hanya jarang dapat merehabilitasi napi, tetapi juga cenderung membuat individu lebih jahat, mengulangi lagi perbuatannya, dan kembali ke penjara. Dengan menggunakan penjara sebagai jawabannya untuk orang-orang ekonomi rendah (mayoritas narapidana saat ini), tidak hanya merupakan masalah keamanan masyarakat, tetapi juga mengabadikan siklus pemiskinan. Banyak resiko kesehatan dari kepadatan penjara, termasuk penyebaran penyakit infeksi, seperti TBC dan HIV. Pengalaman oleh negara Barat saat dilakukannya penambahan lapas, justeru diiringi dengan bertambahnya jumlah narapidana. Merupakan perubahan fundamental dalam melakukan pendekatan terhadap kejahatan, pelaku, dan tempatnya di dalam masyarakat dan perubahan fokus perhatian tindakan-tindakan penitensier dari "pidana dan isolasi" ke "keadilan restoratif dan reintegrasi". Kebijakan formulasi alternatif keringanan pidana penjara jika ditinjau dengan maqâshid al-syarîah Imam Syatibi berbanding lurus dengan nilai menjaga agama (al-dîn), jiwa (al-nafs), keturunan (al-nasl), harta (al-mâl) dan akal (al-aql).

Kebijakan alternatif keringanan pada pelaksanaan penjara hanya merupakan salah satu solusi. Namun kebijakan demikian lebih merupakan kebijakan parsial. Diharapkan seluruh elemen masyarakat dapat melakukan kebijakan yang bersifat integral, bagaimanapun Kongres-kongres PBB 
menyatakan bahwa "the basic strategy of criminal policy" yaitu menciptakan kebijakan sosial kausatif dan meniadakan faktor-faktor penyebab dan kondisi yang menimbulkan terjadinya kejahatan (yang dapat menyebabkan orang dipenjara).

\section{Pustaka Acuan}

Abubakar, Lastuti. "Revitalisasi Hukum Adat Sebagai Sumber Hukum dalam Membangun Sistem Hukum Indonesia." Jurnal Dinamika Hukum 13, no. 2 (2013): 319-331.

Arief, Barda Nawawie. Perbandingan Hukum Pidana, Edisi Revisi, Jakarta: Raja Grafindo, 2010.

- Beberapa Aspek Kebijakan Penegakan dan Pengembangan Hukum Pidana. Bandung: Citra Aditya Bakti, 1998.

- Bunga Rampai Kebijakan Hukum Pidana. Semarang: Kencana Prenada Media Group, 2014.

. Kapita Selekta Hukum Pidana. Bandung: Citra Aditya Bakti, 2010. . Tujuan dan Pedoman Pemidanaan. Semarang: Pustaka Magister, 2017.

- Beberapa Aspek Pengembangan Ilmu Hukum Pidana: Pidato Pengukuhan, diucapkan pada Peresmian Penerimaan Jabatan Guru Besar dalam Ilmu Hukum Pada Fakultas Hukum Universitas Diponegoro, Semarang 25 Juni 1994.

. Beberapa Aspek Kebijakan Penegakan dan Pengembangan Hukum Pidana. Bandung: Citra Aditya Bakti, 2005.

- Pembangunan Sistem Hukum Nasional Indonesia. Semarang: Penerbit Pustaka Magister, 2012.

Asnedi, "Pengelolaan Lembaga Pemasyarakatan dengan Segala

Permasalahannya." Jurnal Pemerintahan dan Politik 1, no. 1 (2016). Azizy, Astrid. "Faktor Penyebab Terjadinya Kerusuhan dan Anarki Serta Upaya Penanggulangannya (Studi di Rumah Tahanan Negara Klas 1 Surabaya).” PhD diss., Universitas Brawijaya, 2013.

Bessler, J. D., Revisiting Beccaria’s Vision: The Enlightenment, America's 
Death Penalty, and the Abolition Movement. Nw. JL \& Soc. Pol'y, 4, (2009).

Bianchi, Herman. "Abolition: Assensus and Sanctuary." Abolitionism: Towards a Non-Repressive Approach to Crime (1986): 113-126. . "Pitfalls and Strategies of Abolition." Abolitionism: Towards a NonRepressive Approach to Crime, Free University Press, Amsterdam (1986). . "Pitfalls and Strategies of Abolition." Abolitionism: Towards a NonRepressive Approach to Crime, Free University Press, Amsterdam (1986). . and René van Swaaningen, eds. Abolitionism: Towards a Nonrepressive Approach to Crime: Proceedings of the Second International Conference on Prison Abolition, Amsterdam 1985: with Contributions from Elizabeth Barker...[et Al.]. Free University Press, 1986.

. and H. Bianchi. Justice as Sanctuary: Toward A New System of Crime Control. Vol. 15. Bloomington: Indiana University Press, 1994. Davis, Angela Y. "Racialized Punishment and Prison Abolition." $A$ Companion to African-American Philosophy (2006): 360-369. . and Dylan Rodriguez. "The Challenge of Prison Abolition: A Conversation." Social Justice 27, no. 3 (81 (2000): 212-218.

Dubost, G. "Lorganisation Spatiale et Sociale de Muntiacus Reevesi Ogilby 1839 en Semi-Liberté.” Mammalia 34, no. 3 (1970): 331-355.

. "Observations Ethologiques sur le Muntjak (Muntiacus Muntjak Zimmermann 1780 et M. Reevesi Ogilby 1839) en Captivité et Semi-Liberté." Zeitschrift für Tierpsychologie 28, no. 4 (1971): 387-427. Gilmore, Kim. "Slavery and Prison-Understanding the Connections." Social Justice 27, no. 3 (81 (2000): 195-205.

Hadi, Abdul, dan Shofyan Hasan, "Pengaruh Hukum Islam dalam Pengembangan Hukum di Indonesia." Nurani: Jurnal Kajian Syariah dan Masyarakat 15, no. 2 (2015): 89-100.

Haq, Hamka. Islam Rahmat untuk Bangsa. Jakarta: Wahana Semesta Intermedia, 2009.

Harahap, Zul Anwar Ajim. "Konsep Maqasid Al-Syariah Sebagai Dasar Penetapan dan Penerapannya dalam Hukum Islam Menurut 'Izzuddin 
Bin 'Abd Al-Salam (W.660 H)", Tazkir 9, ( Juli-Desember 2014), h. 180.

Irfan, M. Nurul. Hukum Pidana Islam. Jakarta: Amzah, 2016 Jamaa, La. "Dimensi Ilahi dan Dimensi Insani dalam Maqashid alSyariah", Jurnal Ilmu Syariah dan Hukum 45, no.2, (Juli- Desember 2011), h. 1260.

Kasdi, Abdurrahman. "Maqasyid Syariah Perspektif Pemikiran Imam Syatibi dalam Kitab Al-Muwafaqat", Jurnal Yudisia, (2014), h. 56

Kusumaningsih, Luh Putu Shanti. "Studi Kasus: Derajat Social Anxietypada Narapidana di Lapas Brebes." Intuisi: Jurnal Psikologi Ilmiah 8, no. 1 (2016): 14-19.

Mayrl, Damon. "Fields, Logics, and Social Movements: Prison Abolition and the Social Justice Field." Sociological Inquiry 83, no. 2 (2013): 286-309.

Mu’allim, Amir. "Adat Kebiasaan dan Kedudukannya dalam Perkembangan Hukum Islam di Indonesia." Al-Mawarid 4 (2016): 14-23.

Munir, Sirojul. "Pengaruh Hukum Islam Terhadap Politik Hukum Indonesia." Istinbath: Jurnal Hukum Islam IAIN Mataram 13, no. 2 (2014): 127-180.

Munajat, Makhrus. Studi Islam di PerguruanTinggi. Yogyakarta: Pesantren Nawesea Press, 2008

Monard, A. N. N. E. "Causes et Conséquences du Départ des Jeunes Femelles de Leur Groupe Natal dans un Troupeau de Chevaux Camargue en Semi-Liberté.” PhD diss., Rennes 1, 1992.

Naintyla, Theresia Avila Ledie. "Kerusuhan Narapidana dalam Lembaga Pemasyarakatan (Studi di Lembaga Pemasyarakatan Kelas IIA Wirogunan Yogyakarta).” PhD diss., UAJY, 2010.

Najitama, Fikria. "Sejarah Pergumulan Hukum Islam dan Budaya serta Implikasinya bagi Pembangunan Hukum Islam Khas Indonesia." AlMawarid 17 (2007).

Priyatno, Dwidja. Sistem Pelaksanaan Pidana Penjara di Indonesia. Bandung: Refika Aditama, 2009. 
Putra, I. Putu Satrya Wibawa Sukarsa. "Dampak Kelebihan Kapasitas Lembaga Pemasyarakatan Sebagai Faktor Kriminogenik Terhadap Pengulangan Tindak Pidana oleh Warga Binaan (Studi di Lapas Kelas II A Denpasar).” Kumpulan Jurnal Mahasiswa Fakultas Hukum (2015).

Priyatno, Dwidja. Sistem Pelaksanaan Pidana Penjara di Indonesia. Bandung: Refika Aditama, 2006.

Ramadhan, Choky. Pengantar Analisis Ekonomi dalam Kebijakan Pidana di Indonesia. Jakarta: Institute for Criminal Justice Reform (ICJR), 2016.

Richie, Beth E. "Reimagining the Movement to End Gender Violence: Anti-Racism, Prison Abolition, Women of Color Feminisms, and Other Radical Visions of Justice." U. Miami Race \& Soc. Just. L. Rev. 5 (2015): 257.

Rumadan, Ismail. "Problem Lembaga Pemasyarakatan di Indonesia dan Reorientasi Tujuan Pemidanaan." Jurnal Hukum dan Peradilan 2, no. 2 (2013): 263-276.

Shokhib, M. Yalis. "Kontektualisasi Perkawinan dalam Tinjauan Maqasid Syariah.” Al-Adalah: Jurnal Syariah dan Hukum Islam 2, no. 1 (2017), h. 18 .

Shidiq, Ghofar. "Teori Maqashid al-Syariah dalam Hukum Islam." Majalah Ilmiah Sultan Agung 44, no. 118 (2018), h. 118

Setiyawan, Agung. "Budaya Lokal dalam Perspektif Agama: Legitimasi Hukum Adat ('Urf) dalam Islam." Esensia: Jurnal Ilmu-Ilmu Ushuluddin 13, no. 2 (2012): 203-222.

Serikat Putra Jaya, Nyoman. Pembaharuan Hukum Pidana. Semarang: Pustaka Rizki Putra, 2017.

Septiano, Muhammad Fajar. Jurnal Pidana Kerja Sosial Sebagai Alternatif Pidana Penjara Jangka Pendek. Malang: UB, 2014.

Sosiawan, Ulang Mangun. "Upaya Penanggulangan Kerusuhan di Lembaga Pemasyarakatan." Jurnal Penelitian Hukum De Jure 17, no. 3 (2017): 365-379.

Sularno, M. "Syari'at Islam dan Upaya Pembentukan Hukum Positif di Indonesia." Al-Mawarid 16 (2006). 
Sudarto. Hukum Pidana dan Perkembangan Masyarakat. Bandung: Sinar Baru, 1983.

Sudarto. Hukum Pidana dan Perkembangan Masyarakat. Bandung: Sinar Baru, 1983.

Syafiq, Ahmad. "Rekonstruksi Pemidanaan dalam Hukum Pidana Islam (Perspektif Filsafat Hukum”), Jurnal Pembaharuan Hukum I, no. 2 (Mei - Agustus 2014), h. 183.

Tarigan, Azhari Akmal. "Ta'zir dan Kewenangan Pemerintah dalam Penerapannya." AHKAM: Jurnal Ilmu Syariah 17, no. 1 (2017) 